\title{
How Successful Learners Employ Learning Strategies in an EFL Setting in the Indonesian Context
}

\author{
Ag. Bambang Setiyadi ${ }^{1}$, Muhammad Sukirlan ${ }^{1} \&$ Mahpul $^{1}$ \\ ${ }^{1}$ Faculty of Education, Lampung University, Indonesia \\ Correspondence: Ag. Bambang Setiyadi, Faculty of Education, Lampung University, Indonesia. E-mail: \\ bambang_setiyadi76@yahoo.co.id
}

Received: April 24, 2016 Accepted: May 30, 2016 Online Published: June 2, 2016

doi: 10.5539/elt.v9n8p28 URL: http://dx.doi.org/10.5539/elt.v9n8p28

\begin{abstract}
Numerous studies have been conducted to correlate the use of language learning strategies and language performance and the studies have contributed to different perspectives of teaching and learning a foreign language. Some studies have also revealed that the students learning a foreign language in Asian contexts have been proved to use different learning strategies compared to students that learn the same language in Western countries. The present study was conducted with 73 students of the seventh semester of an English Department in Indonesia. The subjects had been employing learning strategies in an EFL setting in the Indonesian context. The data in this study were collected by administering a questionnaire of language learning strategies and a test of language proficiency. With the Cronbach's alpha of the measurement at .92 and the alphas of the skill-based strategies at $.78, .75, .79$ and .77 for strategies for listening, speaking, reading and writing respectively, the criteria on reliability of internal consistency for the 80 items of the measurement were very high so that the strategies were justified to be grouped into a scale. The empirical data in this study shows that different language skills were significantly correlated with the use of different learning strategies. The skill-based categories of language learning strategies introduced in this study, which cover cognitive, metacognitive and social strategies in each category, can be used to portray learners' use of language learning strategies when learners learn the four language skills of English as a foreign language in Indonesian context. The findings suggest that language teachers need to condition the process of teaching and learning in order for their students to use effective learning strategies according to the language skills that leaners are learning.
\end{abstract}

Keywords: Learning strategy measurement, EFL learners, skill-based strategy, Indonesian context, language performance.

\section{Introduction}

Different instruments have been developed to identify what learning strategies language learners employ in learning a foreign language. Instruments that have been validated and extensively used for language learning strategies may not measure all strategies that learners employ in learning English as a foreign language, especially in the context of EFL settings. To identify language learning strategies of learners of EFL in the Indonesian setting, a measurement developed in the basis of their cultural setting needs to be explored.

Numerous studies have revealed that learners from different cultures may learn a foreign language in different ways. The students learning a foreign language in Asian contexts have been proved to use different learning strategies compared to students that learn the same language in Western countries. Therefore, a measurement of language learning strategies that considers the context of EFL students in Asia, especially in Indonesia, is needed in order to portray the learning strategies more thoroughly in the their context.

By identifying how the use of English learning strategies is correlated to their language skills, language teachers in the country may expect their students to learn a foreign language more successfully. Language teachers can condition their teaching processes in order for their students to use their effective strategies or training their students to use the strategies when language learnes learn individual skill.

As with other self report survey questionnaires, the measurement for language learning strategies used in this study may have limitations. The limitations include the fact that learners may not fully understand how to respond to the questions of the questionnaire or they may not answer the questions in a frank manner. Further 
research with different ways of collecting data needs to be undertaken to verify how the use of language learning strategies grouped under the language skills contribute to language performance as the findings of this study indicate. This study has proposed taxonomy of language learning strategies consisting of skill-based categories. This classification is not final; further studies need to be done to replicate the findings related to this newly developed measurement so that more consistent findings become available within and across populations. Particularly important is more information on how students from different age levels and different cultural backgrounds use language learning strategies in EFL contexts. The number of the students participated in this study is small and they were not randomly chosen, hence making difficult to generalize the findings of this study to any Asian context. However, the participants involved in this study share important common attributes with language learners in other Asian settings, mainly in that they learn English as a foreign language by separated language skills. It would be worthwhile conducting other studies in EFL tertiary settings to explore whether the language learning categories provided in this study also contribute to similar success as the findings of this study indicate.

\subsection{Research Questions}

The purpose of this article is to determine the reliability of a skill-based category of strategy questionnaire in identifying the use of language learning strategies and to determine what learning strategies successful learners employ in an EFL setting in the Indonesian context. The following two research questions are addressed:

1) How reliable is a skill-based category of strategy questionnaire in identifying the use of learning strategies?

2) What learning strategies do successful learners employ in an EFL setting in the Indonesian context?

\subsection{Previous Studies on Language Learning Strategies}

Numerous studies have determined that the use of language learning strategies significantly predicts success in learning English, and that some individual strategies are more predictive of success than others. Studies by Bidabadi and Yamat (2011), Dreyer and Oxford (1999), Ghafournia (2014)) and Md Yunus, Sulaiman and Embi (2013) provide evidence on a significant relationship between strategy use and ESL proficiency. Another study (Bialystok and Frohlich, 1978) suggests that learning strategies affect language achievement. Their study, which explored variables of classroom achievement in second language learning, showed that many factors were correlated with language achievement, but only two of them: aptitude and strategy use were statistically significant in predicting achievement. A similar study on the effect of language learning strategies on achievement conducted by Park (1997) also indicates that the use of language learning strategies accounted for 13 to $14 \%$ of the total variation of the achievement scores.

An important issue is to what extent language learning strategies contribute to the success of EFL learning. It is assumed that the students who have employed certain strategies would report better language achievement. In Bialystok's study (1981), the strategy most responsible for achievement on all tasks was naturalistic practice or practice for communication, and formal practice or practice for learning appeared to show less relationship to achievement. Huang and Van Naerssen (1987) also conducted a study using a similar classification of language learning strategies introduced in Bialystok (1981). The strategy measurement used to investigate learning strategies in oral communication by Chinese students in Huang and Naerssen's study (1981) was derived from Rubin's inventories (1975). The findings of their study also supported the findings of the previous study by Bialystok (1981), which suggested the superiority of functional practice to the other two strategies: formal practice and monitoring. Another study by Md Yunus, Sulaiman and Embi (2013), which used the Strategy Inventory for Language Learning (SILL) developed by Oxford (1990), found that gifted students used more indirect strategies: metacognitive, affective, social, compared to direct strategies: memory, cognitive, compensation. Another similar study that used the SILL was conducted by Park (1997). His study, which involved Korean university students, indicated that cognitive strategies were more predictive of language achievement scores than were metacognitive strategies (p. 216). A study conducted by Kamran (2013) also revealed that a statistically significant and positive relationship exists between Iranian EFL learners' overall reading strategy use and the scores of their reading comprehension test; to assess the use of language learning strategies this study used Survey of Reading Strategy or SORS developed by Mokhtari and Sheorey's (2002) measurement. Another study that identified the relationship between the use of listening strategies and listening proficiency levels in the Iranian learning context by Bidabadi and Yasmat (2011) also indicated that the Iranian EFL freshman university students of three different listening proficiency groups employed meta-cognitive strategies more frequently than cognitive and socio-affective strategies. In their study the strategy questionnaire developed by Vandergrift was used to measure the use of students' listening strategies (p. 28).

Different classification schemes and instruments have been developed for assessing the use of language learning 
strategies. The most widely used measurement for language learning strategies is the SILL, which was reported to have high validity in several studies (Oxford \& Burry-Stock, 1995). The version 7.0 of SILL, which has 50 items to measure the use of learning strategies in learning English as a foreign language, consists of memory strategies, cognitive strategies, and compensation strategies, metacognitive strategies, affective strategies, and social strategies (Hsio \& Oxford, 2002). The SILL has been used in different countries with different contexts. Ahamad Shah, Ismail, Esa and Muhamad (2013) used the SILL to measure the use of language learning strategies of English for specific purposes in Malaysia. In another study conducted in Asian context, the SILL was used to measure the use of language learning strategies by college students in Philippines (Querol, 2010). Radwan (2011) also used the SILL to identify the relationship between the use of language learning strategies (LLS) and gender and English proficiency of university students in Oman. In Iran Saeb and Zamani (2013) also used the SILL to investigate learning strategies and beliefs about language learning in high-school students and students attending English institutes (see also Takallou, 2011). Chang (2011) also used the SILL to find out the profile of learning strategy use of students in Taiwan. Yu and Wang (2009) used the measurement to identify the use of learning strategies in China. The SILL was also used in Botswana to identify the types of language learning strategies the students use in learning and the relationship between the language learning strategies chosen and their age/level of schooling, their proficiency, and their self-efficacy beliefs (Magogwe \& Oliver, 2007).

However, Grainger (1997) suspects the inadequacy of the SILL since he found that the students of Asian backgrounds do not follow traditional patterns of strategy use as identified in other major studies of language learning strategies. Park (1997) also provides an argument that not all strategies the students employed in learning English in his study were inventoried in Oxford's SILL (p. 217). In another study Park (2011) also found out that the classification of the SILL proposed by Oxford (1990) did not fit the data of his research which was analyzed through confirmatory factor analysis (CFA) to test apriori factor structures in the relationships between observed and latent variables. He suggests that classification system of the SILL should be reinvestigated to understand better the structures of the measurement and the psychometric properties of the instrument including the construct validity. His suggestion is in line with the findings of a study by Hsio and Oxford (2002), which involved 534 undergraduate EFL students in Taiwan. The studies with the participants from the Asian students provide empirical evidence that suggests reevaluating the SILL even though the findings of their studies seem to be contradictory with the findings in a study by Ardasheva and Tretter (2013), whose data was collected from ESL students in the United States.

Language learners from different cultures may learn the same language in different ways (Woodrow, 2005). Students learning a foreign language in Asian contexts may use different learning strategies from those learning the same language in Western countries as suspected by Park $(1997,2011)$. A number of studies in the respect to the use of learning strategies in different cultures have been conducted with the students from different Asian countries (Park, 1997, 2011; Grainger, 1997; Gan, 2004; Nisbet, Tindall, \& Arroyo, 2005). Therefore, a study on how EFL students in Asia learn English by language skills is needed in order to portray their use of learning strategies in their cultural settings. Setiyadi (2014) proposed an alternative measurement for language learning strategies for Indonesian students in learning English in the EFL tertiary setting. The measurement, which is named the Language Learning Strategy Questionnaire or the LLSQ, was used in this study. Different from the SILL of Oxford (1990), in the LLSQ language learning strategies are classified under skill-based categories and each skill category consists of three groups of strategies: cognitive, metacognitive and social strategies. The three groups of strategies are common strategies among researchers on language learning strategies (Fillmore, 1979; O’Malley, Stewner-Manzanares, Kupper \& Russo, 1985; Oxford, 1990; Politzer \& Groarty, 1985). The grouping consisting cognitive, metacognitive and social strategies is also supported with the CFA indicated in a study by Woodrow (2005), which used Schmidt and Watanabe's (2001) classification. In her study most of the participants were Asian students, including students from Indonesia, where the present study was conducted.

\section{Methodology.}

\subsection{Subjects}

The present study was conducted with 73 students of the seventh semester of an English Department in the Faculty of Education in Indonesia. The reason for selecting such a sample was that all subjects had been employing learning strategies in an EFL setting in an Asian context. The age of the students ranged from 19 to 21 . Almost all of the participants could communicate in English in both spoken and written forms. Because the participants' field of this study majored in English from a department of a university in the country, the result of the study might not be generalized to language learners from a larger set of disciplines or from different parts of the country but rather it is indicative. 


\subsection{Instruments}

The data in this study were collected by administering two instruments, namely a questionnaire and tests. The LLSQ was used to measure the use of language learning strategies. The LLSQ includes 4 categories of learning strategies: speaking strategies, listening strategies, reading strategies and writing strategies and each category consists of 20 items. In total the LLSQ has 80 items and each category has learning strategies that are grouped under cognitive, metacognitive and social strategies. Following Oxford's (1990) Strategy Inventory of Learning Strategies (SILL), the use of their learning strategies provided in the LLSQ is arranged in five-Likert Scale, ranging from $1=$ never used, to $5=$ always used. All items of the LLSQ are highly correlated with the Cronbach's alpha at .92 and the alphas of the skill - based strategies are $.78, .75, .79$ and .77 for strategies for listening, speaking, reading and writing respectively.

Regarding proficiency level of the learners, a version of a retired ITP-TOEFL test, was considered as an appropriate test. The test was a standardized test used by the university in which the participants were studying to test English proficiency of its students as prerequisite before their graduation. The test consists of three parts, namely: listening, structure, and vocabulary and reading. In the listening section, there are 50 items to be completed in 30 minutes. The structure section has 40 items (60 minutes) while the vocabulary and reading section has 60 items (60 minutes).Since this study focuses on language skills, only two parts of the test were considered, namely the listening and reading parts, and the scores of structure and grammar usage were not considered in this study. To gain the scores the other two language skills: speaking and writing, the learners were given relevant tests. Their writing skill was measured on the basis of unity, coherence, accuracy and vocabulary use while their speaking skills were measured based on their ability of fluency, pronunciation and grammar use. To get more reliable scores of the last two tests, which were developed for the purpose of this study, the mean scores of two raters were calculated.

\subsection{Data Analysis}

As mentioned earlier, in the LLSQ the students were provided with 80 items with 20 items in each skill-based category (speaking, listening, reading, and writing). Each skill-based category of strategies consisted of 3 groups of strategies, namely: cognitive strategies, metacognitive strategies, and social strategies. The data obtained from the questionnaire were first computed-coded with the help of SPSS 16.0 for Windows. To measure the internal consistency of the hypothesized scales, Cronbach's alpha coefficients of internal consistency were computed for each category. Alpha coefficient scores for each category were obtained and the results are presented in Table 1.

Table 1: Cronbach's alpha values for subscales and total scale

\begin{tabular}{lll}
\hline Multi-item scale & Number of items & Cronbach's Alpha $(\mathrm{n}=73)$ \\
\hline Learning strategies of listening category & 20 & .787 \\
Learning strategies of speaking category & 20 & .758 \\
Learning strategies of reading category & 20 & .795 \\
Learning strategies of writing category & 20 & .771 \\
All strategies of language learning & 80 & .922 \\
\hline
\end{tabular}

In order to find out how the learners' strategy use and their performance of each skill correlated, Pearson Product-Moment correlation analysis was undertaken. Before running the correlation analysis, scores for the three strategy groups in each skill were obtained by summing across items and then dividing by the number of items. The learning strategy use was grouped according to the language skills and the learning strategy use was grouped according to language skills each of which consists of three groups of language learning strategies, namely cognitive, metacognitive, and social learning strategies. The analysis was run to correlate the use of the three strategies in each skill with the score of the skill.

\section{Result}

As a single measurement the LLSQ has been developed based on a theory- driving decision related to the four language skills, the measurement needs to be supported with empirical data to identify how the developed strategies measure the hypothesized scales. As a result of the reliability analyses the strategies used by the students were justified to be grouped under one single measurement to assess the learning strategies used by the language learners involved in this study. The items included under the language skill categories in the 
questionnaire, which consists of 20 items in each skill, also represent scales with high internal consistency and they meet the criteria the reliability of the scales.

Table 2: Pearson correlation coefficients among skill-based strategies

\begin{tabular}{lllll}
\hline & $\mathrm{A}$ & $\mathrm{B}$ & $\mathrm{C}$ & $\mathrm{D}$ \\
\hline Listening strategies (A) & $1.00^{* *}$ & & & \\
Speaking strategies (B) & $.753^{* *}$ & $1.00^{* *}$ & $1.00^{* *}$ & $.665^{* *}$ \\
Reading strategies (C) & $.599^{* *}$ & $.656^{* *}$ & $1.00^{* *}$ \\
Writing strategies (D) & $.573^{* *}$ & $.613^{* *}$ & & \\
\hline
\end{tabular}

${ }^{*} p<0.05 ;{ }^{* *} p<.01$.

The data in Table 2 indicate that Pearson $r$ correlation revealed how the strategies had inter- correlations among them. The four strategies were positively and significantly correlated and shared substantive amount of variance. The correlation analysis between the strategies uncovers a close relationship among strategies that were used in learning the four language skills.

Listening strategies and speaking strategies turned out to be the most highly correlated among the four strategies $(\mathrm{r}=.75, \mathrm{p}=.00)$, followed by the correlations between reading strategies and writing strategies $(\mathrm{r}=.66, \mathrm{p}=.00)$. The inter-correlations among the categories imply that increased frequency of strategy use under one category is associated with an increase in the use of the other categories. To the degree that they correlate, strategies share variance, and the magnitude of $\mathrm{r} 2$ indicates the amount of variance that is interrelated (Hatch \& Lazaraton, 1991, p.440-1). The correlation between listening and speaking strategies is .75 and it indicates that the two categories of language learning strategies overlap to the extent of $r^{2}$ (or. 562). The overlap of the two strategies is $56.2 \%$, suggesting that more than one half of the variance in listening strategies can be accounted for by the variance of speaking strategies and vice versa. The variance of reading and writing strategies that overlap is 43\% (r. 66) while the other strategies overlap lower than $43 \%$.

The rank correlation among the strategies of the four skills may also imply that use of strategies under a certain category is related to the use of other strategies under another certain category. In this study the use of listening strategies was more closely correlated to that of speaking strategies $(r=.75, p=.00)$ than the use of reading strategies $(\mathrm{r}=.59, \mathrm{p}=.00)$ or writing strategies $(\mathrm{r}=.57, \mathrm{p}=.00)$. On the other hand, the use of reading strategies was more closely correlated to that of writing strategies $(r=.66, p .00)$ than that the use of speaking $(r=.61, p$ $=.00)$ or that of listening strategies $(\mathrm{r}=.57, \mathrm{p} .00)$.

Table 3: Pearson correlation coefficients between skill-based categories and language skills

\begin{tabular}{llll}
\hline & Cognitive strategies & Metacognitive strategies & Social strategies \\
\cline { 2 - 4 } Listening & $.376^{* *}$ & .126 & $.286^{*}$ \\
Speaking & $.257^{*}$ & .200 & $.343^{* *}$ \\
Reading & $.448^{* *}$ & $.248^{*}$ & -.056 \\
Writing & .035 & $.381^{* *}$ & .226 \\
\hline
\end{tabular}

${ }^{*} p<0.05 ;{ }^{* *} p<.01$.

To identify the correlation between the use of the language learning strategies under cognitive, metacognitive and social strategies with the language skills, correlation analyses were undertaken. Table 3 summarizes the correlation between the mean score of learning strategies under each category with the score of every language skill. The correlation analysis indicates that the frequency of the strategy use under the cognitive and social categories was significantly and positively correlated with the scores of listening and speaking. The frequency of strategy use of the cognitive and metacognive categories of reading was significantly and positively correlated with the reading score while the use of social strategies turned out to be negatively correlated with the score of reading. The strategies of writing under the three categories were positively correlated and the use of metacognitive strategies was the only category of learning strategies significantly correlated with the score of 
writing.

\section{Discussion}

\subsection{Research Question 1}

\section{Skill-Based Category of Learning Strategy as an Alternative}

In assessing internal consistency, the Cronbach alpha reliability is the most appropriate reliability index to be used on continuous data, such as that produced by a Likert-type scale (Oxford \& Burry-Stock, 1995). The criteria on reliability of internal consistency of each category in this study were met so that the strategies under the categories were justified to be grouped into skill-based categories, namely: language learning strategies grouped under listening, speaking, reading and writing categories. The criteria on reliability of internal consistency for the 80 items of the measurement were very high with the Cronbach's Alpha .92; therefore, the strategies were justified to be grouped into a scale. The classification system that a learning strategy measurement consists of skill-based categories and each category covers cognitive, metacognitive and social strategies may contribute classification schemes of learner strategies.

The validity of individual predictor instrument and combinations of predictor instruments is determined by correlational analysis and extensions of correlational analysis to multivariate analysis (Nunnally, 1978). The validity of the instrument in the present study, especially its predictive validity, was determined by measuring predictive relationship between the use of the instrument and language performance. As indicated in Table 3, all of the skills of language were significantly correlated with the use of certain groups of language learning strategies. It implies that the skills of language can be predicted by the use of certain language strategies; if language learners use more frequently certain strategies in learning one language skill, their skill will increase better. The correlations between the use of language learning strategies and the language skills may be interpreted that the questionnaire has predictive validity to the success in learning the language skills of English as a foreign language.

In line with the findings by Purpura (1997) and Wenden (1991), the intercorrelation among the strategies as shown in Table 2 may be interpreted as a sign of mutual conceptual dependence among strategies. This provides evidence that learners employ all strategies under the four language skills and they do not rely on a single category or certain strategies in learning foreign language. The finding of this study seems to answer a concern that various classification systems of language learning strategies have been developed for research purpose but little attention has been paid to students' learning goals or teaching a new language (Chamot, 2004). The skill-based categories of language learning strategies introduced in this study can be considered to portray learners' use of language learning strategies when learners learn a foreign language and to identify effective learning strategies for each language skill. The equal numbers of language learning strategies between the spoken and written language and between the receptive and productive skills developed in this questionnaire may be a response to the limitations of some studies, as suggested in a study by Tragant, Thompson, and Victori (2013). They have developed a new measurement for language learning strategies in foreign language contexts and provided a thorough analysis of their measurement but the analysis of their study does not include oral production strategies (p.105). Many institutions, especially in Asian countries, provide language learners with classes based on skill instruction, namely listening, speaking, reading, and writing classes. By identifying what strategies of the skills contribute to the success in learning a foreign language, language teachers can teach these strategies to less successful learners when they learn the language by skills as suggested by Rivera-Mills and Plonsky (2007) that a learning strategy category can be used to identify what successful learners; therefore, these strategies can be taught to less successful learners.

The rank correlation as shown in Table 2 may imply that learning strategies for the oral communication of English proficiency (speaking skill) have closer processes to the other oral communication of the proficiency (listening skill). On the other hand, the written English proficiency (reading skill) has closer processes to the other written proficiency (writing skill). To some extent, it may support the natural order hypothesis of Krashen (1985) that there may be a natural order which relatively exist learners in acquiring a foreign language, even though Krashen and Terrel (1983) refer it to the acquisition of grammatical rules. In the present study there is indication that the learners acquire listening and speaking skills through a closely correlated process, and they acquire reading and writing skills through another closely correlated way. It is argued that the process of speaking takes place after language learners acquire listening skill and the process of writing takes place after the acquisition of reading skill. This is also argued that the process of learning a foreign language begins with the spoken language and, then, the process will be followed by the written language. In the acquisition of the spoken language listening seems to play a role as the first process and is followed by speaking while in the acquisition of 
the written language reading comes first and is followed by writing.

\subsection{Research Question 2}

\section{Language Learning Strategies in Relation to Language Performance}

Numerous studies have been conducted to correlate the use of language learning strategies and language performance and the studies have contributed to different perspectives of teaching and learning a foreign language. To mention some, Magogwe and Oliver's (2007) study, which involved students primary, secondary and tertiary levels, indicated that in general there was no significant interaction between proficiency and learning strategies though there was an indication of interaction between them at the primary level. Nisbet, Tindall and Arroyo (2005) found out that only minimal correlation between learning strategies and proficiency existed. To correlate between strategy use and proficiency Hong-Nam and Leavell's (2006) study only indicated that language learning strategies develop along continuum from novice learners to expert.

A study by Wong and Nunan (2011), however, indicated that different frequency of strategy use was significantly different between the more effective and the less effective students and the finding in a study by Jurkovic (2010) metacognitive strategies proved to be significantly correlated with language performance. However, there is little literature which specifically focuses on the roles of language learning strategies in relation to the language skills separately. This present study partly confirms previous studies on how learners' learning strategies were correlated to each language skill.

\subsubsection{The Role of Learning Strategies in Listening}

The data in Table 3 indicates that the frequency of the strategy use under two categories: the cognitive category and the social category were significantly correlated with the skill of listening. Studies on the role of learning strategies in relation to the skill of listening, separated from the other skills of language, are not easily found in the literature. A study that demonstrated the learner's perceptions towards the use of meta-cognitive processes while listening to a spoken text in English was conducted by Bidabadi and Yamat (2013). It was found in their study that the learners believe that metacognitive strategies play an important role to help them become good foreign language listeners but there was no evidence whether the metacognitive strategies were significantly correlated with their listening skill; in their study only the perceptions of the students towards the use of metacognitive strategies were measured.

In the present study it can be argued that in learning English as a foreign language the learners benefitted from the cognitive and social strategies in listening. It may be easily understood that by using the social strategies, which trigger them to communicate with other people, and cognitive strategies, which make them practice using the language, the students will develop their skill of listening. Practicing in using the language both with other people (social strategies) and practicing in using the language by themselves (cognitive strategies) seems to be the key to their success in listening. It is not irrational that in developing the skill of listening learners rely on social interaction in the context of English learning.

\subsubsection{The Role of Learning Strategies in Speaking}

Similar to the correlation analysis in listening as indicated in Table 3, in speaking two groups of categories: cognitive and social strategies were significantly correlated with the score of speaking. The finding is similar to that by Murray (2010), which showed cognitive strategy use had the strongest correlation to the skill of speaking in acquiring Korean as a foreign language; different from the findings in Murray's study, in this study social strategy use was also significantly correlated with speaking. This may be argued that speaking is a language skill which involves an interlocutor(s) and the process of involving other people improves the acquisition of the skill. An investigation on the preference of using learning strategies learning by Liyanage, Bartlett, Birch and Tao (2012) found that Chinese EFL learners reported more use of metacognitive strategies for speaking and listening but their study did not explore whether the frequency of the strategy use was correlated to their proficiency.

In present study it is understood that the power of the social and cognitive strategies in improving the skill of listening also works in promoting the skill of speaking. In developing the skill of speaking it is also the case that the learners in the present study benefitted from practicing the language both through their social interaction and practicing in using the language by individually. It may be argued that the two skills of the spoken language: listening and speaking have relatively similar language learning strategies that play an important role to develop learners' skills.

\subsubsection{The Role of Learning Strategies in Reading}


The correlation analysis as shown in Table 3 indicates that the learning strategies under the cognitive and metacognitive categories played an important role in reading comprehension; they were significantly correlated with the skill of reading. The finding of this study is in line with the finding of a study in China by Yu and Wang (2009) that cognitive and metacognitive strategies significantly correlated with language achievement. However, in their study it is not clear whether reading comprehension was tested or not. A similar study with respect to the reading skill in China (Zhang \& Seepho, 2013) explored only metacognitive strategy use in reading comprehension. The results of their study showed that there was significant positive correlation between the overall metacognitive strategies and the reading achievement and the high proficiency students demonstrated higher frequency in using most of metacognitive strategies than the low proficiency students.

That the cognitive strategies, as well metacognitive strategies, were significantly correlated with the reading score in this study generates the interest for further discussion. It may be understood that the function of the metacognitive strategies is a powerful "tool" in learning English and directs the execution of learning processes. These findings seem to support the notion that metacognitive processes refer to the control or executive processes that direct cognitive processes and lead to efficient use of cognitive strategies (Forrest-Pressley \& Waller, 1984).

The data in Table 3 indicate that not only were social strategies insignificantly correlated but they were negatively correlated with the reading scores. Social strategies are commonly found in a language learning context and these strategies are not well explored in general education. These strategies were investigated and explicitly stated in studies on language learning conducted by Fillmore (1979), O'Malley, Stewner-Manzanares, Kupper and Russo (1985), Oxford (1990) and Politzer and Groarty (1985). The social category includes not only all processes that take place in groups, but also individual activities in social settings aimed to acquire another language. Related to reading in the present study, strategies that involve other people seem not to play an important role in acquiring the skill. The empirical data as shown in Table 4 suggests the more learners use social strategies, the less successfully they will acquire the reading skill. It may be argued that reading, which refers to a problem-solving task and background experience is required in the task (Richardson \& Morgan, 1997), involving other people in this process of acquiring a foreign language is not essential.

\subsubsection{The Role of Learning Strategies in Writing}

It is interesting to note that, consistent with the other skill of the written language: reading, in writing the frequency of metacognitive strategy use was significantly correlated with the writing skill. Different from reading, in writing the significant correlation of the frequency of metacognitive strategy use is not followed by the significant correlation of cognitive strategy use. This needs a further discussion why the learners have succeeded in acquiring the skills of the written language by the strengths of the metacognitive and cognitive strategies only in reading but it was not found that the use of the cognitive strategies contributes to the success in developing their writing skill. Even though the relationship between the use of metacognitive strategies and performance has been investigated in numerous studies (Magogwe \& Oliver, 2007; Nisbet et al, 2005; Sun, 2013), studies on the specific relationship between the use of metacognitive strategies and writing performance can be hardly found in the literature. A study which identified the use of writing strategies and writing performance was conducted by Chien (2012), in which the data on the writing strategies were collected through think-aloud protocol, uncovered strategies employed by students from the time they began to read the writing prompt until they had completed their writing. The finding in the study revealed that the two groups reported their thoughts about the use of writing strategies and the strategies between the two groups proved to be significantly different. Actually, various studies investigated the correlation between the use of language learning strategies with language achievement or performance but the skill of writing was not tested in their studies (Murray, 2010; Nisbet et al, 2005; Wong \& Nunan, 2011).

As the empirical data shown in Table 3 indicate that only metacognitive strategies were significantly correlated with the skill of writing, it can be hypothesized that the function of the metacognitive strategies in directing and controlling cognitive processes will work effectively when language learners make use of their background knowledge while they are reading. When they are concerned with expressing their ideas in a written form, namely writing, it seems that the learners use avoidance strategy and they do not rely very much on their schemata or background knowledge which functions to direct their cognitive processes and lead to efficient use of the cognitive strategies. Different from the skill of reading, the effectiveness of the metacognitive strategies seems not to be followed by the power of the cognitive strategies in the skill of writing. It may be argued that the power of metacognitive strategies to control or execute processes that direct cognitive processes in learning another language will be effective when the process of learning needs learners' schemata as it happens to reading process. Similar to the relationship between the strategy use and learners' proficiency of the spoken language, in 
the written language it may also be argued that the two skills of the written language: reading and writing have relatively similar language learning strategies that play an important role to develop the skills, namely the metacognitive strategies.

In sum, the empirical data in this study showed that different language skills were significantly correlated with the use of different learning strategies. It may be concluded that some language learning strategies will be more effective for improving certain skills while some others will be better for other skills. Language teachers need to condition the process of teaching and learning in order for their students to use language learning strategies accordingly when teaching English as a foreign language according to skills.

\section{Acknowledgments}

We would like to thank the anonymous reviewers for their insightful comments on the earlier version of this paper and their patience. This study on was supported by the Ministry of Research, Technology and Higher Education of Indonesia with Project No. 84/UN26/8/LPPM/2016.

\section{References}

Ahamad Shah, M. L., Ismail, Y., Esa, Z., \& Muhamad, A. J. (2013). Language learning strategies of English for specific purposes students at a public university in Malaysia. English Language Teaching, 6(1). http://dx.doi.org/10.5539/elt.v6n1p153

Ardasheva, Y., \& Tretter, T. R. (2013). Strategy Inventory for Language Learning-EFL student form: Testing for factorial validity. The Modern Language Journal, 97(2), 474-489. http://dx.doi.org/10.1111/j.1540-4781.2013.12011.x

Bialystok, E., \& Frohlich, M. (1978). Variables of classroom achievement in second language learning. Modern Language Journal, 62(7), 327-335. http://dx.doi.org/10.1111/j.1540-4781.1978.tb02403.x

Bialystok, E. (1981). The role of conscious strategies in second language proficiency. Modern Language Journal, 65, 24-35. http://dx.doi.org/10.2307/326204

Bidabadi, F. S., \& Yamat, H. (2011). The relationship between listening strategies used by Iranian EFL freshman university students and their listening proficiency levels. English Language Teaching, 4(1). http://dx.doi.org/10.5539/elt.v4n1p26

Bidabadi, F. S., \& Yamat, H. (2013). EFL Learners' Perceptions towards Meta-Cognitive Strategy Use in English Language Listening. GEMA Online Journal of Language Studies, 13(3).

Chang, C. (2011). Language learning strategy profile of university foreign language majors in Taiwan. Electronic Journal of Foreign Language Teaching, 8(2), 201-215.

Chamot, A. (2004). Issues in language strategy research and teaching. Electronic Journal of Foreign Language Teaching, 1(1), 14-26.

Chien, S. (2012). Students' use of writing strategies and their English writing achievements in Taiwan. Asia Pacific Journal of Education, 32(1), 93-112. http://dx.doi.org/10.1080/02188791.2012.655240

Dreyer, C., \& Oxford, R. L. (1996). Learning strategies and other predictors of ESL proficiency among Afrikaans speakers in South Africa. In R. L. Oxford (Ed.), Language Learning Strategies in the World (pp. 61-74). Honolulu: University of Hawaii.

Fillmore, L. W. (Ed.). (1979). Individual differences in language ability and language behavior. New York: Academic Press.

Forrest-Pressley, D. \& Waller, T.G. (1984). Cognition, metacognition, and reading. New York: Springer-Verlag. http://dx.doi.org/10.1007/978-1-4612-5252-8

Gan, Z. (2004). Attitudes and strategies as predictors of self-directed language learning in an EFL context. $\begin{array}{lllll}\text { International Journal of Applied } & \text { Linguistics, } & \text { 14(3), }\end{array}$ http://dx.doi.org/10.1111/j.1473-4192.2004.00071.x

Ghofournia, N. (2014). Language learning strategy use and reading Achievement. English Language Teaching, 7(4). http://dx.doi.org/10.5539/elt.v7n4p64

Grainger, P. R. (1997). Language learning strategies for learners of Japanese: investigating ethnicity. Foreign Language Annals, 30(3), 378-385. http://dx.doi.org/10.1111/j.1944-9720.1997.tb02360.x

Hatch, E., \& Lazaraton, A. (1991). Design and statistics for applied linguistics. Boston, Massachusetts: Heinle \& Heinle Publishers. 
Hong-Nam, K., \& Leavell, A. G. (2006). Language learning strategy use of ESL students in an intensive English learning context. System, 34(3), 399-415. http://dx.doi.org/10.1016/j.system.2006.02.002

Hsiao, T., \& Oxford, R. L. (2002). Comparing theories of language learning strategies: A confirmatory factor analysis. The Modern Language Journal, 86(3), 368-383. http://dx.doi.org/10.1111/1540-4781.00155

Huang, X., \& Van Naerssen, M. (1987). Learning strategies for oral communication. Applied Linguistics, 8(3), 287-307. http://dx.doi.org/10.1093/applin/8.3.287

Jurkovic, V. (2010). Language learner strategies and linguistic competence as factors affecting achievement test scores in English for specific purposes. TESOL Journal, 1(4). http://dx.doi.org/10.5054/tj.2010.234765

Kamran, K. S. (2013). Does reading strategy use predict and correlate with reading achievement of EFL learners? International Journal of Research Studies in Language Learning, 2(2), 29-38.

Krashen, S. D. (1985). The Input Hypothesis: Issues and Implications. New York: Longman, Inc.

Krashen, S. D., \& Terrel, T. D. (1983). The Natural Method. Hayward, California: Alemany Press.

Liyanage, I., Bartlett, B., Birch, G. \& Tao, T. (2012). To Be or Not To Be" Metacognitive: Learning EFL Strategically. Electronic Journal of Foreign Language Teaching, 9(1), 5-25.

Magogwe, J. M., \& Oliver, R. (2007). The relationship between language learning strategies, proficiency, age and self-efficacy beliefs: A study of language learners in Botswana. System, 35(3), 338-352. http://dx.doi.org/10.1016/j.system.2007.01.003

McLaughlin, B. (1990). "Conscious" versus "unconscious" learning. TESOL Quarterly, 24(4), 617-634. http://dx.doi.org/10.2307/3587111

Md Yunus, M., Sulaiman, N. A., \& Embi, M. A. (2013). Malaysian gifted students' use of English language learning strategies. English Language Teaching, 6(4). http://dx.doi.org/10.5539/elt.v6n4p97

Murray, B. (2010). Students' language learning strategy use and achievement in the Korean as a foreign language. Foreign Language Annals, 43(4). http://dx.doi.org/10.1111/j.1944-9720.2010.01105.x

Nisbet, D.L., Tindall, E. R, \& Arroyo, A. A. (2005). Language learning strategies and English Proficiency of Chinese university students. Foreign Language Annals, $38(1)$. http://dx.doi.org/10.1111/j.1944-9720.2005.tb02457.x

Nunnally, J. C. (1978). Psychometric Theory (2nd edition). Sydney: McGraw-Hill Book Company.

Oxford, R. (1990). Language learning strategies: what every teacher should know. Boston: Heinle \& Heinle Publishers.

Oxford, R. \& Burry-Stock, J. A. (1995). Assessing the use of language learning strategies worldwide with the ESL/EFL version of the Strategy Inventory for Language Learning (SILL). System, 23(1), 1-23. http://dx.doi.org/10.1016/0346-251X(94)00047-A

Park, G. (1997). Language learning strategies and English proficiency in Korean university students. Foreign Language Annals, 30(2), 211-221. http://dx.doi.org/10.1111/j.1944-9720.1997.tb02343.x

Park, G. (2011). The validation process of the SILL: A confirmatory factor analysis. English Language Teaching, 4(4). http://dx.doi.org/10.5539/elt.v4n4p21

Politzer, R.L. \& McGroarty, M. (1985). An exploratory study of learning behaviors and their relationship to gains in linguistics and communicative competence. TESOL, 19(1), 103-123. http://dx.doi.org/10.2307/3586774

O’Malley, M.J, Stewner-Manzanares, G. Kupper, L. \& Russo, R. P. (1985). Learning strategies used by beginning and intermediate ESL students. Language Learning, 35(1), 21- 44. http://dx.doi.org/10.1111/j.1467-1770.1985.tb01013.x

Purpura, J. E. (1997). An analysis of the relationship between test takers' cognitive and metacognitive strategy use and second language test performance. Language Learning, 47(2), 289-325. http://dx.doi.org/10.1111/0023-8333.91997009

Sun, L. (2013). The effect of meta-cognitive learning strategies on English learning. Theory and Practice in Language Studies, 3(11), 2004-2009. http://dx.doi.org/10.4304/tpls.3.11.2004-2009

Querol, M. B. (2010). College students' use of affective and social language learning strategies: A classroom-based research. Philippine ESL Journal, 5, 2-21. 
Radwan, A. A. (2011). Effects of L2 proficiency and gender on choice of language learning strategies by university students majoring in English. Asian EFL Journal, 13(1).

Richardson, J. S., \& Morgan, R. F. (1997). Reading to learn in the content areas (third edition). California: Wadsworth Publishing Company.

Rivera-Mills, S. V., \& Plonsky, L. (2007). Empowering students with language learning strategies: A critical review of current issues. Foreign Language Annals, 40(3). http://dx.doi.org/10.1111/j.1944-9720.2007.tb02874.x

Saeb, F., \& Zamani, E. (2013). Language learning strategies and beliefs about language learning in high-school students and students attending English Institutes: are they different? English Language Teaching, 6(12). http://dx.doi.org/10.5539/elt.v6n12p79

Setiyadi, A. B. (2014). Skilled-Based Categories: An Alternative Measurement for Language Learning Strategies. Journal of Language Teaching and Research, 5(2). http://dx.doi.org/10.4304/jltr.5.2.360-370

Sun, L. (2013). The effect of meta-cognitive learning strategies on English learning. Theory and Practice in Language Studies, 3(11).

Takallou, F. (2011). The effect of metacognitive strategy instruction on EFL learners' reading comprehension performance and metacognitive awareness. Asian EFL Journal, 13(1). http://dx.doi.org/10.4304/tpls.3.11.2004-2009

Tragant, E., Thompson, M. S., \& Victori, M. (2013). Understanding foreign language learning strategies: A validation Study. System, 4(1), 95-108. http://dx.doi.org/10.1016/j.system.2013.01.007

Wenden, A. (1985). Learner strategies. TESOL Newsletter, 19(5), 4-7.

Wenden, A. (1991). Metacognitive strategies in L2 writing: a case for task knowledge. Georgetown University Round Table on language and Linguistics, 302-321.

Wong, L. L. C., \& Nunan, D. (2011). The learning Styles and strategies of effective language learners. System, 39(2), 144-163. http://dx.doi.org/10.1016/j.system.2011.05.004

Woodrow, L. (2005). The challenge of measuring language learning strategies. Foreign Language Annals, 38(1). http://dx.doi.org/10.1111/j.1944-9720.2005.tb02456.x

Yu, Y., \& Wang, B. (2009). A study of language learning strategy use in the context of EFL curriculum and pedagogy reform in China. Asia Pacific Journal of Education, 29(4), 457-468. http://dx.doi.org/10.1080/02188790903309041

Zhang, L., \& Seepho, S. (2013). Metacognitive strategy use and academic reading achievement: Insights from a Chinese context. Electronic Journal of Foreign Language Teaching, 10(1), 54-69.

\section{Copyrights}

Copyright for this article is retained by the author(s), with first publication rights granted to the journal.

This is an open-access article distributed under the terms and conditions of the Creative Commons Attribution license (http://creativecommons.org/licenses/by/4.0/). 